\title{
Of Horse Fish And Frozen Words
}

\author{
KIM CAMPBELL
}

\section{I} recent decades, the functioning of language both as an independent structure and as the structuring vehicle for other systems, as for example literature, has riveted critical attention, to such an extent that we tend to forget at times that the question of how language signifies did not originate with Saussure, although his formulation remains one of the most articulate in this century. It is nonetheless evident-and even a cliché-that in every era there are those who wrestle with the relationship of signifier to signified, feeling perhaps that some essential key to the working of the human spirit must be contained in the symbolic system structuring not only articulation but thought itself.

François Rabelais is one of those who wrestle. The problem of language weaves its way in and out of his works as Rabelais recombines and juxtaposes words and even syllables, pushing language to the limits of expression, of meaning, of signification. While on one hand therefore, Rabelais' personal bout with language places him squarely within the current of linguistic inquiry as old as human thought, it is at the same time intensely reflective of specific Renaissance preoccupations, as in the latter part of the fifteenth and during the sixteenth century, Europe underwent what might in modern day usage be termed an "identity crisis," or re-evaluation of the sense of self and non-self, of the real and the imaginary, of meaning and its representation. This re-evaluation was greatly influenced by the acquisition of new topographical knowledge, to wit, the "discovery," from the European point of view, of the Americas and the ocean routes to the Orient. Certainly, the profound sociocultural changes of the Renaissance were not generated solely by geographical discoveries. Nevertheless, these discoveries were of prime importance in the development of new thought patterns and their articulation. The attempts, in travel journals, to describe and name the unknown, to integrate and reconcile it with prior phenomenological systems, revealed the fragility of the bond between signifier and signified: The application, by the travel journalist, of existing linguistic systems to unknown objects, concepts or rituals often 
tended to block rather than facilitate the communication of information as the relationship of signifier to signified was displaced by the use of existing signifiers in new representational contexts.

The ambiguity of this topographical discourse was not lost on Rabelais: His Quart Livre ${ }^{1}$ explores, among other subjects, the question of the linguistic disruption inherent in Renaissance topographical journals in general, and, as Abel Lefranc has noted ${ }^{2}$, most probably in the travel journals of Jacques Cartier ${ }^{3}$ in particular. Indeed, Lefranc's research reveals that in all probability Rabelais met and talked with Cartier, and perhaps even visited the area around Saint-Malo, the point of departure for Cartier's voyages. "Jamet Brayer," the navigator of Pantagruel's ship, is commonly held to be Cartier. ${ }^{4}$ Rabelais reacts, then, to the linguistic disruption he perceives in Cartier's discourse; our first question therefore concerns the parameters of this disruption as expressed in Jacques Cartier's travel journals.

Cartier's travel journals represent a functional topographical discourse; that is, they are designed to provide necessary information both to subsequent explorers and to those who would commercially exploit the newly discovered territories. As a result, Cartier's topographical discourse devoted considerable space to navigational records: water depth, contours of landmarks, distances and hazards. For example, he comments on the approach to Grand-Kirpon Island:

Y a deux entrees l'une vers l'eist et l'aultre vers le su de l'isle mais il se fault donner garde de la bande et pointe de l'eist car se sont bastures et pays somme et fault renger l'isle de l'ouaist à la longueur de demy cable ou plus pres qu'il veult et puis s'en aller surs le su, vers le [Karpont]. Et aussi se fault donner garde de trois basses qui sont soubz l'eau au chenal devers l'isle de l'est. Il y a de fontz par le chenal troys ou quatre brasses et beau fons. L'autre entree gist est nordest et su vers l'ouaist à saultez à terre. $^{5}$

Such precise records of previous voyages were necessary to the efficient and successful completion of subsequent voyages, given the practical limitations of the science of navigation during the Renaissance: Although latitude could be established, longitude could not be fixed with any degree of accuracy before the development of a marine chronometer, in the eighteenth century. Moreover, in northern latitudes, approaching magnetic north, the compass is subject to extreme variation, a natural phenomenon which immeasurably increased the difficulty of accurately determining location. ${ }^{6}$ In short, the necessity of navigating using the records of prior voyages engendered a 
pragmatic, functional discourse motivated first by the desire to survive and second by the wish to profit, in a commercial sense, from the voyage.

This functional topographical discourse is based upon and accords primary importance to the function of the observer, the concept of truth-of-sight. The eyewitness provides an acceptable transmission of information; his account of what he saw is deemed to communicate with adequate accuracy the verity of the situation witnessed. The eyewitness is the authority. As François Hartog notes, "Il s'agit en effet de l'oeil comme marque d'énonciation; d'un 'j'ai vu' comme intervention du narrateur dans son récit, pour faire preuve."7 Thus, the verb "to see" confers credibility and hence reality upon the object seen. Paradoxically, though, through the effort to assimilate the object seen into existing epistemic and lexical systems, by virtue of giving it a name, or readily decodible signifier, the seer may impart a quality of unreality, of fantasy, to the object seen and described in terms of the existing lexicon and attendant linguistic framework. For example, Cartier describes a walrus seen during his second voyage: "Il y a dedans ladicte ripviere plusieurs poissons qui ont forme de chevaulx lesquelz vont à la terre de nuyct et de jours à la mer ainsi qu'il nous fut dict par nos deulx hommes et de sesdits poissons vismes grand nombre dedans ladite ripviere." ${ }^{8}$ The reader accepts the truth of the sighting; it is an eyewitnessing account. Yet Cartier's very efforts to describe the unknown in terms of the known-a fish in the form of a horse ${ }^{9}$-serve to distance the reader from the object seen. As Cartier interposes his discourse between the object seen and his reader, between the sign he invents and the object he interprets, he creates a discursive space which represents neither the real nor the unreal, but rather the point at which the two converge and become indistinguishable. ${ }^{10}$

The creation of an ambiguous discursive space, in which the communicative function of language is, to say the least, displaced, goes a long way toward explaining the persistance of Western European legends concerning little known lands. Jacques Cartier, for instance, speaks in his journals of the "golden lands" of North America. This legend is based on "hearsay," that is, what the explorer has been told rather than what he has seen; but just as his readers are willing to accept the explorer's eyewitness account, so he is willing to accept in good faith the eyewitness account of others. The narrator (in this case, Cartier) validates what he has heard by his own acceptance of it: Already established in the position of authority as the eyewitness, the narrator can extend his personal authority to what he has heard rather than seen. As Hartog explains it: 
Le j'ai entendu prend le relais du j'ai vu, quand ce dernier n'est pas possible ou n'est plus possible. En vertu du principe que l'oreille y aille quand l'oeil, n'y peut aller, le $j$ 'ai entendu peut valoir autant que le $j$ 'ai $v u$, non pas en valeur absolue, mais relativement, c'est-à-dire, relativement à moi. En effet, vous n'avez pas lieu de me croire moins quand je dis j'ai entendu que lorsque je dis j'ai vu. ${ }^{11}$

For example, Cartier quotes an Indian chief who says that in the land of the "Saguenay," "il y a infiny or rubiz et aultres richesses et y sont les hommes blancs comme en France et acoustrez de draps de laine. Plus dict avoir veu aultre pays où les gens ne mangent poinct et n'ont poinct de fondement et ne digerent poinct ains font seullement eaue par le verge."12 Thus, the observations of the Indian chief, reported to Cartier, constitute, as does Cartier's own eyewitness account, an acceptable source of information, and indeed, in a discursive space where language cannot function as the arbiter of the real and the fantastic, the idea of a land where men never eat nor digest is no more inconceivable than a fish in the form of a horse.

We see then that Cartier, through his very attempts to communicate his discoveries, looses the signifier from its moorings and sets it adrift in a veritable sea of referential possibilities. Rabelais, in his Quart Livre, explores these possibilities, using this topographical text as a pretext, adding an allegorical dimension, multiplying the levels of meaning within the discursive space created (albeit unwittingly) by the journalist. In the opening paragraphs of the Quart Livre, Rabelais evokes this topographical pretext employing the discursive patterns of the travel journals as a forme fixe in order to locate his own writing with respect to that of the topographer:

On moys de juin au jour des festes Vestales, celluy propre on quel Brutus conquesta Hespaigne et subjugua les Hespaignolz; on quel aussi Crassus l'avaricieux feut vaincu et deffaict par des Parthes, Pantagruel, prenant congé du bon Gargantua son pere, icelluy bien priant (comme en l'Elise primitive estoit louable coustume entre les saincts Christians) pour le prospere naviguaige de son filz et toute sa compaigne, monta sus mer au port de Thalasse, accompaigné de Panurge, frere Jan des Entomeures, Epistemon, Gymnaste, Eusthennes, Phizotome, Carpalim et aultres siens servituers et domestiques anciens; ensemble de Xenomanes le grand voyageur et traverseur des voyes perilleuses lequel, certains jours paravant, estoit arrivé au mandement de Panurge. ${ }^{13}$

The formal evocation of the topographer's discourse becomes evident if the above is compared with Cartier's record of his own departure: 
Après que missire Charles de Mouy chevallier seigneur de la Milleraye et visamiral de France eut prins les sermens et faict jurez les cappitaine maistres et conpaignons desditz navires de bien et loyaulment soy porter au service du Roy soubz la charge dudit Cartier partimes du havre et port de Sainct Malo avecques lesdits deux navires du port e'environ soixante tonneaulz chaincun les deux de soixante ung homme le vigntiesme jour d'apvril oudit an mil cinq cens trante quatre. ${ }^{14}$

Cartier notes the data and place of departure, type of equipment and personnel abord, leader of the expedition, as well as the commendation proferred at the moment of departure. Rabelais follows the same format, including a rather lenghty description of the equipment (in subsequent paragraphs). ${ }^{15}$

Examples of intertextuality of this kind are numerous in the Quart Livre, but to return to the more specific question of the linguistic disruption often occasioned by the topographer's descriptions of his experiences, we find Rabelais' thoughts on the subject most clearly and poetically expressed in the chapters concerning the "parolles gelées," an episode detailing the encounter between Pantagruel's ship and the word-icebergs. Now Rabelais' Renaissance source of inspiration, Jacques Cartier, describes various encounters with icebergs during the course of his voyages in the North Atlantic. For example Cartier notes the approach to one island blocked by ice: "Et Le XXIe jour dudit moys de may partismes dudit hable avecques ung vent de ouaist et fumes portez au nort ung quart de nordeist de Cap de Bonne Viste jucques à l'Isle des Ouaiseaulx laquelle isle estoit toute avironnee et circuitte d'un bancq de glasses rompues et departies par pieces." 16 Indeed, navigation is rendered impossible at times by an excess of ice: "Et pour la grant nombre de glasses qui estoint le long d'icelle terre nous convint entrer en ung havre nonmé Saincte Katherine."17 Rabelais situates his own narrative within the context provided by Cartier's discourse, yet breaks free of this framework by altering the message. The blocks of ice are, in fact, the frozen remains of the sound of last winter's battle:

Icy est le confin de la mer glaciale, sus laquelle feut, au commencement de l'hyver dernier passé, grosse et felonne bataille entre les Arismapiens et les Nephelibates. Lors gelerent en l'air les parolles et crys des homes et femmes, les chaplis des masses, les hurtys des harnois, des bardes, les hannissemens des chevaulx et tout aultre effroy de combat. ${ }^{18}$

The myth of the frozen words does not, of course, originate with Rabelais. Plutarch, in the Moralia ${ }^{19}$, sketches the outline of such a myth; the idea is 
reworked by Balthazar Castiglione as well as by the Renaissance humanist Caelis Calcagninus, although, in Jean Plattard's opinion, Rabelais' immediate source was the Moralia $^{20}$. In any case Rabelais, sensitive to the ambiguities of the existing discursive system, makes use of the myth of the frozen words to question the communicative function of language. ${ }^{21}$

I have noted with respect to Cartier's travel journals that the transmission and especially the verification of information relies on the eyewitness, the observer, as intermediary or interpreter between the object/event and the destinataire. Rabelais begins by undermining this basic tenet of the discursive system. Pantagruel and his group do not at first see anything, and are quite disturbed by the breakdown of the normal sequence of perception:

En pleine mer nous banquetans, gringnotans, divisans et faisans beaulx et cours discours, Pantagruel se leva et tint en pieds pour discouvrer à l'environ. Puys nous dist: 'Compaignons, oyez vous rien? Me semble que je oy quelques gens parlans en l'air, je n'y voy toutesfoys personne. Escoutez.' A son commandement nous feusmes attentifz, et à pleines aureilles humions l'air, comme belles huytres en escalle, pour entendre si voix ou son aulcun y seroit espart; et pour rien n'en perdre à l'exemple de Antonin l'Empereur, aulcuns oppousions nos mains en paulme darriere les aureilles. Ce neantmoins protestions voix quelconques n'entendre.

Pantagruel continuoit affermant ouyr voix diverses en l'air, tant de homes comme de femmes, quand nous feut advis, ou que nous les oyons pareillement, ou que les aureilles nous cornoient. Plus perseverions escoutans, plus discernions les voix, jusques à entendre motz entiers. Ce que nous effraya grandement, et non sans cause, personne ne voyans et entendens voix et sons tant divers, d'homes, de femmes, d'enfans, de chevaulx. ${ }^{22}$

When at last the travellers do "see" the words, their description defies categorization, for in Rabelais' version of the myth, the crystallization of sound is represented by that most supremely visual of all effects. The sounds are colored: "Lors nous jecta sus le tillac pleines mains de parolles gelées, et sembloient dragée perlée de diverses couleurs. Nous y vismes des motz de gueule, des motz de sinople, des motz d'azur, des mots de sable, des motz dorez." ${ }^{23}$ Thus in his own time, Rabelais returns to the principle of sight-asverification, only to reintroduce the problem already posed by Cartier's journal: That of the horse-fish, or disruption of the link between signifier and signified. By evoking the synesthetic qualities of language-the colors of sound-Rabelais questions the existing linguistic system not only on the level 
of expression or representation, but on that of perception as well. If all things are possible just beyond the known horizon of conceptualization, in the "New World" discovered by Renaissance explorers, then sounds may indeed have colors; perhaps it is only the limitations imposed on us by our senses that prevent us from perceiving those colors. The difficulty of naming the unknown of saying what $i s$, may then be a function of perception, yet perception itself, the way we see, is structured by language. That is to say, as twentieth century linguists and critics have noted, that there is no pure perception; the conceptualizaion of 'what is' is indissolubly linked to and influenced by its articulation; the signifier shapes our perception of the signified. And the signifier is arbitrary: Sounds do not have colors because the existing linguistic system does not describe "sound" in that way. ${ }^{24} \mathrm{~A}$ different system, as Rabelais hints in his version of the myth of the frozen words, may pair sound with colors creating a different series of symbolic correspondences between signifier and signified.

Indeed, for Rabelais, the world would seem to be, as Baudelaire puts it several centuries later, a "forêt de symboles" where "les parfums, les couleurs et les sons se répondent." 25 At the edge of the unknown, one code may evoke another, as we are made to understand through Rabelais' very choice of colors. The frozen words are not 'red' and 'blue' and 'green' and 'black;' not 'rouge et bleu,' 'vert et noir,' even though these color-words were part of the common French lexicon in Rabelais' time.$^{26}$ Instead, Rabelais chooses-and certainly not be accident-to evoke a symbolic system in which the signifiers are normally colors rather than words, in which communication is effected by means of a code of shade and shape, rather than through patterns of sound and silence. In short, Rabelais evokes well-known patterns of heraldic signifiers through his use of the color-words "gueule" and "azur," "sinople" and "sable." The linguistic signifiers-the words-are then represented in heraldic terms-with colors-fusing the two symbolic systems. Thus it is that in Rabelais' imaginary world, just as in the 'real' world Jacques Cartier depicts in his journals, systems of signs clash and intermingle, forming new codes, perhaps, but disrupting existing communicative networks, for the frozen words, when thawed, are indecipherable, at least by Pantagruel and his crew: "les quelz, estre quelque peu eschauffez entre nos mains, fondoient comme neiges, et les oyons realement, mais ne les entendions, car c'estoit languaige barbare". 27

Although Rabelais does not linger long upon the thought, he succeeds, in the few pages constituting Pantagruel's encounter with the frozen words, in articulating, if not in resolving, even to his own satisfaction, the difficulties 
inherent in the establishment of any system of communicative signs, especially at a time when new knowledge was being acquired at a pace which made its assimilation into the existing epistemological system problematic: The Renaissance was certainly a period of tremendous excitement, but also an era of deep-seated malaise, for the process of naming the unknown, thereby mastering it and tranforming it into the known, implied not only the definition of this unknown - the other, the non-self-but redefinition of the self. Discoveries and innovations called into question the Western European concept of itself and the world. And, in the double process of naming the unknown and renaming the self, as the signified was redefined and displaced, the link with the signifier was disrupted, creating an open, uncharted discursive space as vast and deep and troublesome as the Renaissance "ocean sea" itself. It is evident that the end result of this process would be a new expanded system of being and meaning; as Normand Doiron puts it, "Quand les voyageurs auront été partout, et qu'ils auront enfin nommé tous les lieux, le monde sera à nouveau universel." 28 But, in the meanwhile, in the early years of the Renaissance, as the old system of conceptualization, representation and communication was crumbling before the massive onslaught of new information, the horizon literally and figuratively opened up to limitless-and no doubt in the eyes of many, frightening-possibilities. Rabelais, sensitized to this phenomenon by the writing of Jacques Cartier and other travel journalists, confronts the question on its own ground: Rather than retreating to a scholar's vantage point, from which he could, with a certain intellectual sang-froid, analyse the problem, Rabelais recreates it, turning the linguistic system upside down in the process, but all the while hinting at undreamed-of realms of signification, reaching to capture those ephemeral possibilities of meaning drifting just beyond the horizon. In fact, for Rabelais, the phenomenon of linguistic disruption - the horse-fish-is not a barrier to expression, but a catalyst generating novel patterns of literary mimesis, impelling the writer to recast and reformulate the discursive and linguistic structures of his era.

\section{New York University}

\section{Notes}

1 François Rabelais, Le Quart Livre, in Oeuvres complètes, ed. Pierra Jourda (Paris, Garnier, 1962), II. All quotes refer to this edition.

2 Abel Lefranc, Les navigations de Pantagruel. Etude sur la géographie rabelaisienne (Paris, Leclerc, 1905), p. 57; 63.

3 Jacques Cartier, Relations, ed. Michel Bideaux (Montréal, Presses de l'Université de Montréal, 1986). All quotes refer to this edition. 
4 In this Jean Plattard agrees with Lefranc. See François Rabelais, Le Quart Livre, in Oeuvres complètes, ed. Jean Plattard (Paris, Belles Lettres, 1955-61), IV, p. 266, note 6.

5 Cartier, Première relation (1534), p. 98; lines 79-87.

6 For a detailed discussion of the difficulties of Renaissance navigation, see J.R. Hale, Renaissance Exploration (New York: Norton, 1968).

7 François Hartog, Le miroir d'Hérodote: Essai sur la représentation de l'autre (Paris. Gallimard, 1980), p. 272. Michel Jeanneret, in his article "Léry et Thevet: comment parler d'un monde nouveau?" in Mélanges à la mémoire de Franco Simone (Geneva: Slatkine, 1983), IV, p. 234, also notes this reliance on the eyewitness account: "L'activité fondamentale ... est celle du regard."

8 Cartier, Deuxième relation (1535-36), p. 133-34; lines 276-80.

9 The etymology of the name of this animal reflects similar modes of perception throughout Europe. The English "walrus" is a "whale-horse" or "horshwael" in Old English; I note as well the German "walross" and the Danish "hvalros." (See the Random House Dictionary of the English Language).

10 A. Cioranescu, in his article "La découverte de l'Amérique et l'art de la description,' RSH 106 (1962), p. 162, comments that, in the Middle Ages, "il ne semble pas que la frontière entre le croyable et l'incroyable lui [au lecteur] ait jamais causé des préoccupations,' an observation which would seem to hold true for the sixteenth century as well. Jean-Claude Morisot speaks of the Renaissance as "une époque de découvertes, où ne cessent de se déplacer les frontières entre possible et impossible, incroyable et réel," in "'L'Histoire d'un voyage fait en la terre du Brésil' de Jean de Léry," CAIEF 27 (1975), p. 39.

11 Hartog, p. 297; 282.

12 Cartier, Deuxième relation (1535-36), p. 176-77; lines 1589-93.

13 Rabelais, p. 31.

14 Cartier, Première relation (1534), p. 96; lines 1-11.

15 Of course Rabelais plays with the topographical discourse from the opening lines of the Quart Livre, presupposing a certain literary competence on the part of his readers, if they are to fully enter into the spirit of the game.

16 Cartier, Première relation (1534), p. 96; lines 21-25.

17 Cartier, Première relation (1534), p. 96; lines 15-17.

18 Rabelais, p. 206.

19 Plutarch, Moralia, trans, Frank Cole Babbitt (Cambridge, MA: Harvard University Press, 1969), I, p. 421: "Antiphanes said humorously that in a certain city words congealed with the cold the moment they were spoken, and later, as they thawed out, people heard in the summer what they had said to one another in the winter."

20 Jean Plattard, L'oeuvre de Rabelais (sources, invention et composition) (Paris, Champion, 1910), p. 240: "Mais il est plus probable que sa source immédiate est ici Plutarque lui-même."

21 The episode of the "parolles gelées" has been interpreted in various ways over the years. Two major currents of thought predominate. The episode has been interpreted as the 


\section{2 / Renaissance and Reformation}

expression of the poetic experience: Jean Guiton, in "Le mythe des paroles gelées", Romanic Review, 31 (1940), p. 13, observes that "le mythe des 'paroles gelées' nous conduit d'abord aux limites du langage des ces étranges régions que rêve d'explorer le poète." More recently, Lawrence Kritzman, in "La Quête de la parole dan le Quart livre de Rabelais," French Forum, 2 (1977), p. 203, notes that "l'écrivain-Rabelais . . vise à libérer son écriture du monde connu en allant au-devant de l'aventure poétique." On the other hand, a number of critics see the "parolles gelées" as a reflection of Rabelais' preoccupation with contemporaneous religious debate: V.L. Saulnier, in Rabelais II (Paris, S.E.D.E.S./C.D.U., 1982), reads the episode as a message of hope in the face of the enforced silence of the evangelists: "Les Paroles 'gelées' représentent donc un silence. Taisons-nous, en présence de l'infortune des temps. Mais gardons confiance: le grain ne meurt pas. La vérité que l'on cache et qui se cache, un jour verra bien paraître. Laissons passer le temps des contraintes et des incompréhensions: il vient un temps où toute parole, conservée dans les glaces, reprend voix et se fait entendre (p. 120)" M.A. Screech, in Rabelais (Ithaca, NY: Cornell University Press, 1979), while noting that "in both books [Tiers Livre, Quart Livre] he [Rabelais] is concerned to show how language can also be a barrier to understanding or reaching the truth (p. 416), " feels, like Saulnier, the linguistic argument in the episode of the frozen words to be secondary to the expression of Rabelais' thought on Christianity "It is no longer an ancient myth of time and eternity; it is a myth of celestial words and ideas lasting to the end of the Christian epoch... Rabelais places the myth within the context of Christian eschatology (p.423)." These interpretations, while interesting, tend to downplay the importance of the travel journal to the genesis of Rabelais' version of the myth of the frozen words. In an era in which the idea of religious reformation, as well as that of aesthetic reform, was of major consequence it is sometimes tempting to read all hermetic passages in light of these preoccupations, forgetting that the discovery of America had an equally great impact on the European community of the sixteenth century.

22 Rabelais, p. 203.

23 Rabelais, p. 206.

24 Although oddly enough, words may have; language is often described as being "colorful."

25 Charles Baudelaire, "Correspondances" in Les Fleurs du mal et autres poèmes (Paris, Garnier-Flammarion, 1964), p. 39

26 See A.J. Greimas, Dictionnaire de l'ancien français (Paris, Larousse, 1969) and Grand Larousse de la langue française (Paris, Larousse, 1977) for the history of the various color words in French.

27 Rabelais, p. 206.

28 Normand Doiron, "Les rituels du départ de quelques voyageurs renaissants," Etudes françaises, 22 (1986), p.15. 